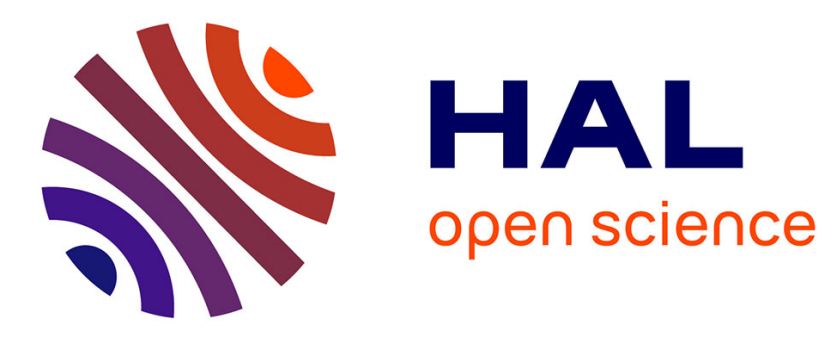

\title{
The potential of earthworms to restore ecosystem services after opencast mining - A review
}

Stéphane Boyer, Stephen D. Wratten

\section{To cite this version:}

Stéphane Boyer, Stephen D. Wratten. The potential of earthworms to restore ecosystem services after opencast mining - A review. Basic and Applied Ecology, 2010, 11 (3), pp.196-203. 10.1016/j.baae.2009.12.005 . hal-02140583

\section{HAL Id: hal-02140583 \\ https://hal.science/hal-02140583}

Submitted on 2 Oct 2019

HAL is a multi-disciplinary open access archive for the deposit and dissemination of scientific research documents, whether they are published or not. The documents may come from teaching and research institutions in France or abroad, or from public or private research centers.
L'archive ouverte pluridisciplinaire HAL, est destinée au dépôt et à la diffusion de documents scientifiques de niveau recherche, publiés ou non, émanant des établissements d'enseignement et de recherche français ou étrangers, des laboratoires publics ou privés. 


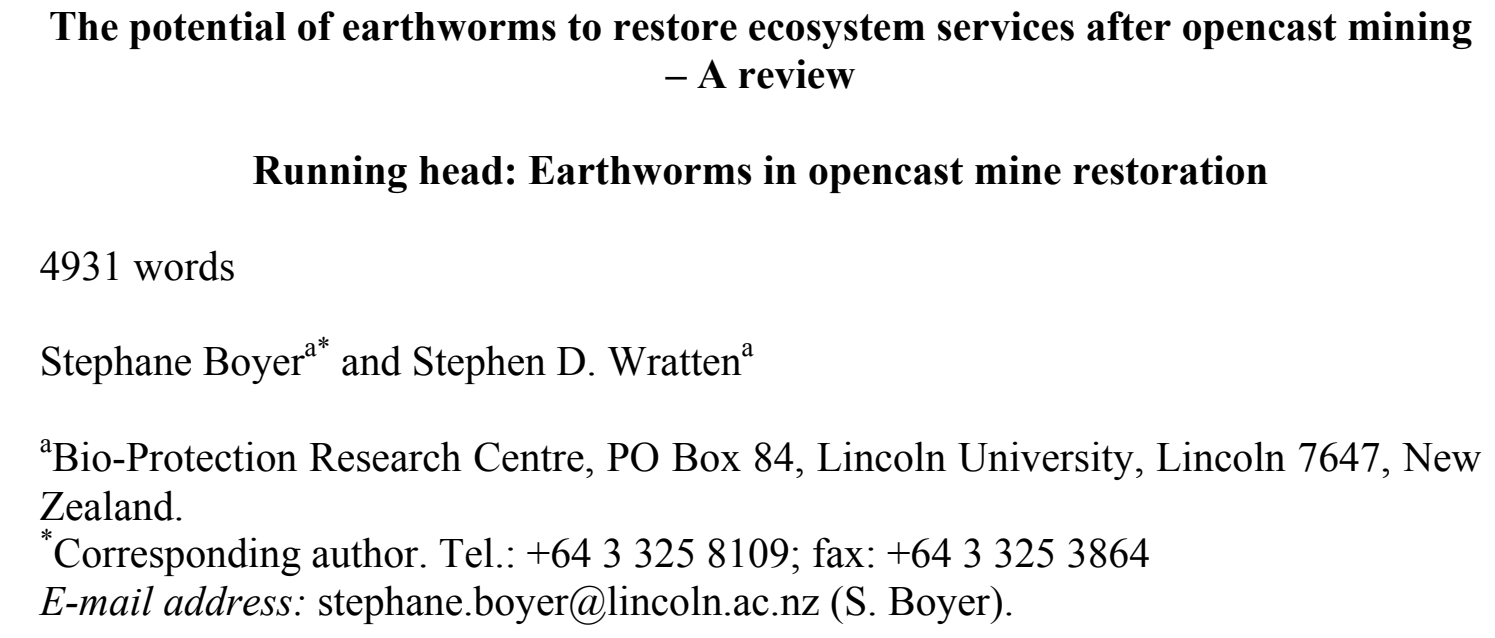




\section{Abstract}

Opencast coal mining has several environmental impacts, which require land rehabilitation when mining operations are finished. For that reason, restoration after such extractive industries' work is common and has been well studied. However, many ecological restoration schemes do not examine to what extent complete and functioning ecosystems have been restored above and below ground. While the aim should be to restore functioning ecosystems, most restoration plans focus only on vegetation and above ground macro-fauna.

Among the potential species that are likely to be important early in mine land restoration, earthworms are particularly good candidates. They provide several ecosystem services that are likely to accelerate soil restoration, improve primary production and facilitate the restoration of a functional ecosystem in mining areas. These services include: increase in topsoil fertility, food for a wide range of predators and recycling of waste organic materials on rehabilitated areas.

Here, we outline some of the challenges specifically facing opencast mining restoration and describe how the ecosystem services provided by earthworms may address some of these challenges.

Keywords: Earthworm introduction; soil rehabilitation; ecological restoration; functioning ecological ecosystems; waste bio-stabilisation

\section{Introduction}

The fundamental role of earthworms in the formation of soils was largely acknowledged by Darwin (1881): "It may be doubted whether there are many other animals which have played so important a part in the history of the world, as have these lowly organised creatures". In a recent review of the potential role of soil macro-invertebrates in ecological restoration, Snyder \& Hendrix (2008) highlighted the importance of earthworms in accomplishing restoration goals in various degraded soils. Here we outline some of the challenges specifically facing opencast mining restoration and describe how the ecosystem services provided by earthworms may address some of these challenges. The unique emphasis of this review is a focus on a specific type of land restoration (opencast mining) for which the potential of earthworms has been scarcely investigated. There are no examples of large-scale use of earthworms for such restoration programmes. This review will address why this ecosystem approach needs to be carried out and discusses the role of functioning earthworm communities in such a restoration programme.

\section{Environmental issues associated with opencast mining}

Opencast mining usually consists of removing vegetation and soil and, when necessary, blasting the underlying rocks to gain access to the desired resource. During this process, several environmental impacts occur that require land restoration when mining operations are finished. The main long-term environmental issues caused by opencast mining include direct vegetation destruction, soil deterioration and water acidification. For that reason, attempts at restoration are common (Plass \& Vogel, 1973; Lyle, 1987; Hossner, 1988; Sengupta, 1993; Smyth \& Dearden, 1998) but are not always based on a sound ecological knowledge.

Direct vegetation destruction 
The vegetation is either cut down or removed with the soil. The resulting denuded landscape is favourable for pioneer, early successional, often introduced species but not for mid- to late-succesionnal plant and animal populations to re-colonise.

\section{Deterioration caused by soil displacement and long-term stockpiling}

Before opencast mining begins, soil is usually removed and stored in stockpiles, sometimes for several years, then spread again at the original place or elsewhere after mining activities have been completed (Lyle, 1987; Scullion, 2002). The soil fauna and flora experience extreme conditions during this phase, as most of the pile is compacted and anaerobic (Abdul-Kareem \& McRae, 1984). Furthermore, structure of soils spread after stockpiling is likely to be destroyed by the bulking process, partly because topsoil is mixed with subsoil overburden materials (Schwenke, Mulligan \& Bell, 2000).

\section{Water acidification following the oxidation of sulfide}

During excavation, sulfide minerals, such as pyrite $\left(\mathrm{FeS}_{2}\right)$, are exposed to oxygen. Pyrite occurs in nearly all types of geological environments and is commonly associated with coal and metallic ore. Oxidation of pyrite leads to the formation of acid in the environment, resulting in low $\mathrm{pH}$ and releasing other metals such as aluminium, iron and trace metals (Lu, Wang, Chen, Xue, Zhang et al., 2005). Rainwater coming into contact with these oxidized minerals then becomes severely acidified and loaded with heavy metals (Lottermoser, 2007).

\section{Opencast mining restoration}

While the aim should be to restore a functioning ecosystem (Bradshaw \& Hüttl, 2001), most restoration plans focus only on vegetation and above-ground macrofauna, which are more visible and more easily manageable. Soil communities, which are less accessible and less visible, are usually ignored (Langer, Davis \& Ross 1999; Majer, Brennan \& Moir, 2007). The reconstruction of an appropriate plant community is essential for the restoration of most degraded land ecosystems and attempts to restore most other aspects of ecosystem structure and function cannot succeed without a functioning ecological community of primary producers (Perrow \& Davy, 2002). Therefore, environmental criteria for restoration success after opencast mining operations are traditionally related to re-vegetation success and plant biomass production (e.g., Smyth \& Dearden, 1998; Koch, 2007). It is usually assumed that the production of self-sustaining vegetation comprising a variety of native plants will in turn support native fauna (Schwenke et al., 2000). However, the enhancement of populations or the addition of other species groups may be necessary in many cases to accelerate ecological succession, ensure native fauna re-colonisation and improve the restoration of a functioning ecosystem (Frouz, Elhottova, Pizl, Tajovsky, Sourkova et al., 2007). Because soil is the component most dramatically altered by opencast mining, soil fauna should be a major focus with regard to the re-establishment of ecosystems on mine sites (Dunger, 1968; Hüttl \& Weber, 2001; Topp, Simon, Kautz, Dworschak, Nicolini et al., 2001; Majer et al., 2007).

\section{The potential roles of earthworms in restoration ecology} Earthworms as soil improvers

Among the potential groups that are likely to be important early in mine-site restoration, earthworms are particularly good candidates. Because they play a major 
113 role in the comminution and mineralisation of organic matter and greatly influence

114 soil structure and chemistry, the presence of a flourishing earthworm community is

115 likely to accelerate soil restoration and improve primary production (Edwards \&

116 Bohlen, 1996). Therefore, earthworms have frequently been used for soil restoration

117 purposes (for a review, see: Butt, 2008; Snyder \& Hendrix, 2008), but never for large-

118 scale restoration of opencast mine sites. By their burrowing activity, earthworms mix

119 and aggregate soil (Blanchart, 1992) and minimize surface water erosion by

120 enhancing soil macroporosity (Francis \& Fraser 1998) and water-holding capacity

121 (Topp et al. 2001). Earthworms consume organic matter and mineral particles and

122 many of the species egest casts that are microbially very active and contain nutrients,

123 which are readily usable by plants (Edwards, 2004). By doing so, they accelerate the

124 topsoil creation process. Sandhu, Wratten, Cullen \& Hale (2005) quantified the value

125 of exotic earthworms' ecosystem services in terms of topsoil creation in pastures in

126 Canterbury, New Zealand (125,000 ha of arable land). The benefits were estimated at

127 between 4 and 65 million USD per year, depending on field type and history. This

128 figure is probably underestimated since it is based on the current low market price of

129 topsoil, which ignores the complex and lengthy processes that created it as well as the

130 direct and indirect costs associated with substituting oil-based input for soil ecosystem

131 functions.

132 Three different ecological guilds of earthworms are commonly differentiated: those

133 inhabiting the leaf-litter, the topsoil or the subsoil (Bouché, 1972; Lee, 1985).

134 Earthworms in different guilds have different feeding preferences and burrowing

135 behaviours that affect their impact on and creation of soil. There is little functional

136 redundancy between groups as each affects the soil structure and nutrient dynamics in

137 a different way. As a result, the impact of all groups is not a reflection of the sum of

138 their individual contributions but is synergistic (Sheehan, Kirwan, Connolly \&

139 Bolger, 2006). Therefore an optimal restoration scheme should focus on species from

140 the three guilds.

141

\section{The role of earthworms in community function}

Because earthworms are integral to the functioning of terrestrial ecosystems, they have the ability to influence plant and soil communities. As an example, seed ingestion and excretion by earthworms have the potential to alter seed germination of numerous plant species (Eisenhauer, Schuy, Butenschoen \& Scheu, 2009). In most cases earthworm digestion was shown to accelerate seed germination by breaking seed dormancy (Ayanlaja et al., 2001) and increasing water permeability of the seed surface (Tomati, Grappelli \& Galli, 1988). However, for some plant species, germination success decreases after digestion by earthworm (e.g., Decaens, Mariani, Betancourt \& Jimenez, 2003). The effect of earthworm excreta on seeds appears to be earthworm and plant species-specific and suggests that plants might have adapted to the ingestion by local earthworms (Eisenhauer et al. 2009). These relationships are likely to contribute to earthworm-mediated changes in vegetation structure (Regnier, Harrison, Liu, Schmoll, Edwards et al. 2009) such as those observed in the recent invasion of European earthworm species in the temperate forests of the North-eastern United States (James \& Hendrix, 2004; Hale, Frelich \& Reich, 2006; Hendrix, Baker, Callaham, Damoff, Fragoso et al., 2006).

In addition to their key role in soil structure and chemistry, and their influence on plant communities, earthworms represent a substantial biomass capable of supporting large communities of vertebrate (e.g., Macdonald, 1983) and invertebrate (e.g., Judas, 1989; Boyer \& Wratten, 2009) predators. Duvigneau (1980) estimated that the 
163 earthworm biomass in a deciduous oak-hornbeam (Quercus-Carpinus) forest in

164 Belgium to be $600 \mathrm{~kg} / \mathrm{ha}$. This can represent more than $98 \%$ of all animal biomass in

165 forest ecosystems (Brockie \& Moeed, 1986) and leads to indirect ecosystem services,

166 as their predators may have positive impacts on seed dispersal (Wall, 2004), reduction

167 of pests (Landis, Wratten \& Gurr, 2000; Symondson, Glen, Erickson, Liddell \&

168 Langdon, 2000; Araj, Wratten, Lister \& Buckley, 2009) and weed-seed populations

169 (Navntoft, Wratten, Kristensen \& Esbjerg, 2009).

\section{Earthworms in opencast mine soils}

\section{Impact of mining activities on earthworms}

173 Soils disturbed and/or moved after mining are particularly hostile to earthworms 174 because of the lack of structure, the compaction during the stockpiling process, low 175 organic matter content, unfavourable moisture conditions and very low pH (Pizl, 176 2001; Curry, 2004). However, natural re-colonisation of soils after mining can occur 177 at a slow rate. Only a few studies in the United Kingdom and Eastern Europe have 178 focused on the impact of opencast mining on earthworm populations. They show that the survival rate of earthworms in the surface of the soil stockpiles can be high enough to act as a reservoir for re-colonisation of re-spread soils (Armstrong \& Bragg, 1984). Because stockpiles are mainly anaerobic and very compact, only the top layer of the pile is suitable for earthworms to survive until the soil is spread again. Individuals surviving the stockpiling process can re-colonise rehabilitated soils within 10 to 30 years (Scullion, Mohammed \& Ramshaw, 1988; Hüttl \& Weber, 2001 Pizl, 2001). Earthworm biomass is then similar to that of the pre-mining state but species composition may differ. Best results are obtained in conjunction with efficient plant restoration programmes. Indeed, the presence of vegetation accelerates the natural recolonisation process because plant roots enhance earthworm burrowing activity (Springett, Gray, Barker, Lambert, Mackay et al., 1998) and more importantly, decaying plant parts provide the necessary food resource.

\section{Introduction of earthworms to mining soils}

Unlike some microorganisms (Jasper, 2007), arthropods (Majer et al., 2007), birds, reptiles and mammals (Nichols \& Grant, 2007), earthworms have limited dispersal capacities (Dunger, 1989; Marinussen \& van den Bosh, 1992) and may require extensive re-introduction in areas requiring restoration following intensive commercial or industrial use. Introduction of earthworms facilitates the creation of topsoil and the establishment of vegetation (Butt, Frederickson \& Morris, 1995; Baker, Brown, Butt, Curry \& Scullion, 2006) as well as the provision of other ecosystem services; see above. Therefore, earthworms have often been targeted as organisms to introduce in restoration programmes involving macro-invertebrates (Butt, 2008; Snyder \& Hendrix, 2008). Introduction of earthworms has been rarely attempted in restored mine soils, however, when it has been attempted, substantial improvements in ecosystem services have been achieved. For example, in an opencast coal mine in Ohio, there was a faster degradation rate of leaf litter within six months after the introduction of Lumbricus terrestris (L.) to small mesocosms in mine spoils (Vimmerstedt, 1983). On a larger scale $\left(400 \mathrm{~m}^{2}\right)$ in the UK, the introduction of six local earthworm species (70 individuals $\mathrm{m}^{-2}$ ) in restored coal mine soils led to an increase in soil aggregation, microbial biomass and carbohydrate content and more generally to higher primary production over a five-year study (Scullion \& Malik, 2000). 
212 The choice of which species to introduce is of primary importance, as several 213 examples of earthworm introductions in landfills and colliery spoils resulted in poor 214 re-colonisation success when unsuitable species were used (see Butt, 2008 for a 215 review). Moreover, the introduction of exotic earthworms can significantly affect 216 other soil organisms and plant communities, as earthworms are integral to the 217 functioning of terrestrial ecosystems within which they have evolved (James \& 218 Hendrix, 2004; Hale et al., 2006; Hendrix et al., 2006). Therefore, it is essential to 219 introduce only those earthworms, which are native or endemic to mine restoration areas if the aim is to restore native ecosystems.

\section{Bio-stabilisation of waste organic materials in mining soil}

Increasing worldwide production of city and industrial waste motivates the research for disposal and recycling options methods alternative to the traditional land filling and open dumping practices. Earthworms have been used to recycle wastes from various origins such as textile (Rosa, Giuradelli, Corrêa, Rörigand, Schwingel et al., 2007), distillery (Suthar \& Singh, 2008), paper (Garg, Gupta \& Satya, 2006) and food industries (Schuldt, Rumi, Gutiérrez-Gregoric, Caloni, Bodnar et al., 2005), as well as city sewage (Neuhauser, Loehr \& Malecki, 1988; Suthar, 2009); see Kale (2004) for a review. Most of these studies have involved only one epigeic species such as Eisenia fetida (Savigny), Eisenia andrei Bouché, Eudrilus eugeniae (Kinberg), Perionyx excavatus (Perrier) or Perionyx sansibaricus (Perrier), although remediation efficiency may vary according to the species as well as waste composition and concentration (Neuhauser et al., 1988; Butt, 1993; Emmerling \& Paulsch, 2001; Khwairakpam \& Bhargava, 2009). In a restoration programme context, knowledge acquired from single-species laboratory or small mesocosm studies needs to be extrapolated to large-scale application of waste directly to the soil, with the aim of benefitting to the whole earthworm community. The supplementary addition of organic waste may be required until decaying plant parts from the rehabilitated vegetation produce enough organic matter.

The addition of organic waste such as sewage sludge to mine re-spread soil could be an optimal solution for land restoration. Indeed, sludge could provide the local earthworm community with the organic matter that it lacks because of the absence of vegetation in the early phase of land restoration. At the same time this waste could be recycled naturally by the earthworms. The use of sewage sludge in this way at restored mine sites in Germany led to an increase in earthworm population density, biomass and burrowing activity (Emmerling \& Paulsch, 2001). In the treated areas, which received 10 to $25 \mathrm{t}$ of sludge per hectare, earthworm population density had doubled after two years compared to the control which had only mineral fertilizer added. Similar results were obtained by Barrera, Andrés \& Alcañiz (2001). However, the authors highlighted the accumulation of heavy metals in earthworm tissue and faeces. Although they are sometimes useful to detoxify soils, the propensity of earthworms to accumulate heavy metals and other toxic materials may present a significant risk of bioaccumulation through the food web (Suthar \& Singh 2009).

\section{Conclusions}

There is a high current interest in the relationship between ecosystem function and biodiversity because the economic value of ecosystem function (ecosystem services) is of global importance (Constanza, d'Arge, de Groot, Farber, Grasso et al., 1997; Daily, 1997). However, biodiversity is declining worldwide at the greatest rate since the last Ice Age (Wilson, 1988) and species extinction rate is expected to continue to 
increase dramatically during the next 50 years if 'biodiversity hotspots' are not protected (Pimm \& Raven, 2000). Because restoration schemes cannot focus on every species in an ecosystem, priority groups are usually selected based on their important role in the ecosystem (keystone species), their high resource requirements and habitat needs (umbrella species), their capacity to arouse public interest and sympathy (flagship species) or their threatened status (Simberloff, 1998; Hunter \& Gibbs, 2007). In mining areas, the restoration of earthworm communities could greatly accelerate land restoration and the re-establishment of a functioning ecosystem. Indeed, earthworm populations have an important impact on several ecosystem services, including direct services and indirect services due to the sustaining of a wide range of predators. Also, the use of earthworms in mine soils can enhance the disposal and stabilisation of organic wastes. Measurement of all these ecosystem services may be necessary to have an accurate idea of the ecological and economic value of rehabilitating earthworm fauna in post-mining land. An appropriate approach to this will require a multi-disciplinary programme (see Sandhu, Wratten, Cullen \& Case, 2008), which includes measuring ecosystem function in the field using a range of experimental methods, which are rapidly becoming available (see Navntoft et al. 2009; Porter, Costanza, Sandhu, Sigsgaard \& Wratten, 2009).

Despite their ecological importance, the services that earthworms provide have been poorly considered in mine land restoration, even in the well-studied mines of eastern Germany (Hüttl \& Weber, 2001) and Western Australia (Majer et al., 2007). With a rapidly-increasing world human population and consequent reductions in biodiversity, such approaches are increasingly important. Research of the type reviewed here on ecosystem services provided by earthworms needs to be provided to end-users in the form of Service Providing Units (SPUs; Luck, Harrington, Harrison, Kremen, Berry et al., 2009). Such units of information inform users about what type of biodiversity is needed to improve ecosystem services by how much ecosystem services thereby improved and how, where and when to deploy the functional biodiversity. Producing such SPUs is a vital requirement for sustainable future mine restoration using earthworms.

\section{Acknowledgments}

This work is funded by Solid Energy New Zealand Limited. We thank Dr Kevin Butt (University of Central Lancashire, UK) and two anonymous reviewers and for their valuable contributions to this review as well as Pryderi Hughes for technical assistance.

\section{References}

Abdul-Kareem, A.W., \& McRae, S.G. (1984). The effects on topsoil of long-term storage in stockpiles. Plant and Soil, 76, 357-363.

Araj, S.E., Wratten, S.D., Lister, A., \& Buckley, H. (2009). Floral diversity, parasitoids and hyperparasitoids - a laboratory approach. Basic and Applied Ecology, 9, 588597.

Armstrong, M.J., \& Bragg, N.C. (1984). Soil physical parameters and earthworm populations associated with opencast coal working and land restoration. Agriculture, Ecosystems \& Environment, 11, 131-143. 
Ayanlaja, S.A., Owa, S.O., Adigun, M.O., Senjobi, B.A., \& Olaleye, A.O. (2001). Leachate from earthworm castings breaks seed dormancy and preferentially promotes radicle growth in jute. HortScience, 36, 143-144.

Baker, G.H., Brown, G., Butt, K., Curry, J., \& Scullion, J. (2006). Introduced earthworms in agricultural and reclaimed land: their ecology and influences on soil properties, plant production and other soil biota. Biological Invasions, 8, 1301-1316.

Barrera, I., Andrés, P., \& Alcañiz, J.M. (2001). Sewage sludge application on soil: Effects on two earthworm species. Water Air and Soil Pollution, 129, 319-332.

Blanchart, E. (1992). Restoration by earthworms (Megascolecidae) of the macroaggregate structure of a destructured savanna soil under field conditions. Soil Biology and Biochemistry, 24, 1587-1594.

Bouché, M.B. (1972). Lombriciens de France, Ecologie et Systématique. Paris: INRA Publ.

Boyer, S., \& Wratten, S.D. (2009). Using molecular tools to identify New Zealand endemic earthworm in a mine restoration project. Proceedings of the $4^{\text {th }}$ International Oligochaete Taxonomy Meeting (4 ${ }^{\text {th }}$ IOTM), in press.

Bradshaw, A.D., \& Hüttl, R.F. (2001). Future minesite restoration involves a broader approach. Ecological Engineering, 17, 87-90.

Brockie, R.E., \& Moeed, A. (1986). Animal biomass in a New Zealand forest compared with other parts of the world. Oecologia, 70, 24-34.

Butt, K.R. (1993). Utilization of solid paper-mill sludge and spent brewery yeast as a feed for soil-dwelling earthworms. Bioresource Technology, 44, 105-107.

Butt, K.R. (2008). Earthworms in soil restoration: Lessons learned from United Kingdom case studies of land reclamation. Restoration Ecology, 16, 637-641.

Butt, K.R., Frederickson, J., \& Morris, R.M. (1995). An earthworm cultivation and soil inoculation technique for land restoration. Ecological Engineering, 4, 1-9.

Constanza, R., d'Arge, R., de Groot, R., Farber, S., Grasso, M., Hannon, B., Limburg, K., Naeem, S., O'Neill, R.V., Paruelo, J., Raskin, R.G., Sutton, P., van den Belt, M. (1997). The value of the world's ecosystem services and natural capital. Nature, 387, 253-260.

Curry, J.P. (2004). Factors affecting the abundance of the earthworms in soils. In: C.A. Edward (Ed.), Earthworm ecology (pp. 91-113). Boca Raton: CRC Press.

Daily, G.C. (1997) Nature's services: societal dependence on natural ecosystems. Washington DC: Island Press. 
Darwin, C. (1881) The formation of vegetable mould, through the action of worms, with observations on their habits. London: William Clowes \& Sons, Limited.

Decaens, T., Mariani, L., Betancourt, N., \& Jimenez, J.J. (2003). Seed dispersion Oecologica, 24, 175-185.

Dunger, W. (1968) Die Entwicklung der Bodenfauna auf rekultivierten Kippen und Halden des Braunkohlentagebaues. Abhandlungen und Berichte des Naturkundemuseums Görlitz 43, 1-256.

Dunger, W. (1989) The return of soil fauna to coal mined areas in the German Democratic Republic. In: J.D. Majer (Ed.) Animals in primary succession - the role of fauna in reclaimed lands (pp. 307-337). Cambridge, Cambridge University Press.

Duvigneau, P. (1980). La synthèse écologique. Paris: DOIN.

Edwards, C.A. (2004). Earthworm Ecology, $2^{\text {nd }}$ edition. Boca Raton: CRC press.

Edwards, C.A., \& Bohlen, P. (1996). Biology of Earthworms, $3^{\text {rd }}$ edition. New York: Chapman Hall.

Eisenhauer, N., Schuy, M., Butenschoen, O., \& Scheu, S. (2009). Direct and indirect effects of endogeic earthworms on plant seeds. Pedobiologia, 52, 151-162.

Emmerling, C., \& Paulsch, D. (2001). Improvement of earthworm (Lumbricidae) community and activity in mine soils from open-cast coal mining by the application of different organic waste materials. Pedobiologia, 45, 396-407.

Francis, G.S. \& Fraser, P.M. (1998). The effects of three earthworm species on soil macroporosity and hydraulic conductivity. Applied Soil Ecology, 10, 11-19.

Frouz, J., Elhottova, D., Pizl, V., Tajovsky, K., Sourkova, M., Picek, T., \& Mal, S. (2007). The effect of litter quality and soil faunal composition on organic matter dynamics in post-mining soil: A laboratory study. Applied Soil Ecology, 37, 72-80.

Garg, P., Gupta, A., \& Satya, S. (2006). Vermicomposting of different types of waste using Eisenia foetida: A comparative study. Bioresource Technology, 97, 391-395.

Hale, C.M., Frelich, L.E., \& Reich, P.B. (2006). Changes in hardwood forest understory plant communities in response to European earthworm invasions. Ecology, 87, 1637-1649.

Hendrix, P.F., Baker, G.H., Callaham, M.A., Damoff, G.A., Fragoso, C., Gonzalez, G., James, S.W., Lachnicht, S.L., Winsome, T., \& Zou, X. (2006). Invasion of exotic earthworms into ecosystems inhabited by native earthworms. Biological Invasions, 8, 1287-1300. 
Hossner, L.R. (1988). Reclamation of Surface-mined Lands. Volume 1. Boca Raton: CRC Press.

Hunter, M.L., \& Gibbs, J.P. (2007). Fundamentals of Conservation Biology, $3^{\text {rd }}$

Hüttl, R.F., \& Weber, E. (2001). Forest ecosystem development in post-mining landscapes: a case study of the Lusatian lignite district. Die Naturwissenschaften, $88,322-329$.

James, S.W., \& Hendrix, P.F. (2004). Invasion of Exotic Earthworms into North America and Other Regions. In: C.A. Edwards (Ed.), Earthworm Ecology (pp. 75-88). Boca Raton: CRC Press.

Jasper, D.A. (2007). Beneficial soil microorganisms of the Jarrah forest and their recovery in bauxite Southwestern Australia. Restoration Ecology, 15, S74-S84.

Judas, M. (1989). Predator-pressure on earthworms - Field experiments in a beechwood. Pedobiologia, 33, 339-354.

Kale, R. (2004). Earthworms: nature's gift for utilization of organic wastes. In: C.A. Edwards (Ed.), Earthworm Ecology (pp. 381-399). Boca Raton: CRC Press.

Koch, J.M. (2007). Restoring a jarrah forest understorey vegetation after bauxite mining in Western Australia. Restoration Ecology, 15, S26-S39.

Khwairakpam, M., \& Bhargava, R. (2009). Vermitechnology for sewage sludge recycling. Journal of Hazardous Materials, 161, 948-954.

Landis, D.A., Wratten, S.D., \& Gurr, G.M. (2000) Habitat management to conserve natural enemies of arthropod pests in agriculture. Annual Review of Entomology, 45, 175-201.

Langer, E.R., Davis, M.R., \& Ross, C.W. (1999). Rehabilitation of lowland indigenous forest after mining in Westland. Science for Conservation, 117, 1-42.

Lee, K.E. (1985). Earthworms: Their Ecology and Relationships with Soils and Plant Growth. Sydney: Academic Press.

Lottermoser, B. (2007). Mine Wastes. Characterization, Treatment and Environmental Impacts. Berlin: Springer-Verlag.

Lu, L., Wang, R., Chen, F., Xue, J., Zhang, P., \& Lu, J. (2005). Element mobility during pyrite weathering: implications for acid and heavy metal pollution at miningimpacted sites. Environmental Geology, 49, 82-89.

Luck, G.W., Harrington, R., Harrison, P.A., Kremen, C., Berry, P.M., Bugter, R., 
455 Dawson, T.P., de Bello, F., Diaz, S., Feld, C.K., Haslett, J.R., Hering, D., 456 Kontogianni, A., Lavorel, S., Rounsevell, M., Samways, M.J., Sandin, L., Settele, J., 457 Sykes, M.T., van den Hove, S., Vandewalle, M., \& Zobel, M. (2009) Quantifying the 458 contribution of organisms to the provision of ecosystem services. Bioscience, 59, 459 223-235.

Lyle, E. (1987). Surface Mine Reclamation Manual. New York: Elsevier Science Publishing.

Macdonald, D.W. (1983). Predation on eartworms by terrestrial vertebrates. In: J.E. Satchell (Ed.), Earthworm Ecology, from Darwin to vermiculture (pp. 393-414). London: Chapman \& Hall Ltd.

Majer, J.D., Brennan, K.E.C., \& Moir, M.L. (2007). Invertebrates and the restoration of a forest ecosystem: 30 years of research following bauxite mining in Western Australia. Restoration Ecology, 15, S104-S115.

Marinussen, J.C.Y, Van Den Bosh, F. (1992). Colonization of new habitats by earthworms. Oecologia, 91, 371-376.

Navntoft, S., Wratten, S.D., Kristensen, K., \& Esbjerg, P. (2009). Weed seed predation in organic and conventional fields. Biological Control, 49, 11-16.

Neuhauser, E., Loehr, R., \& Malecki, M. (1988). The potential of earthworms for managing sewage sludge. In: C.A. Edwards \& E.F. Neuhauser (Eds.), Earthworms in waste and environmental management (pp. 9-31). The Hague: SPB Academic Publishing.

Nichols, O.G., \& Grant, C.D. (2007). Vertebrate fauna recolonization of restored bauxite mines - key findings from almost 30 years of monitoring and research. Restoration Ecology, 15, 104-115.

Perrow, M.R., \& Davy, A.J. (2002). Handbook of Ecological Restoration, Vol. 1. Cambridge: Cambridge University Press.

Pimm, S.L. \& Raven, P. (2000). Biodiversity - extinction by numbers. Nature, 403, 843-845.

Pizl, V. (2001). Earthworm Succession in Afforested Colliery Spoil Heaps in the Sokolov Region, Czech Republic. Restoration Ecology, 9, 359-364.

Plass, W.T., \& Vogel, W.G. (1973). Chemical Properties and Particle-Size Distribution of 39 Surface-Mined Spoils in Southern West Virginia. USDA Forest Service Research Paper, NE27, 1-8.

Porter, J., Costanza, R., Sandhu, H., Sigsgaard, L., \& Wratten, S. (2009). The Value of Producing Food, Energy and Ecosystem Services within an Agro-Ecosystem. Ambio, in press. 
Regnier, E., Harrison, S.K., Liu, J., Schmoll, J.T., Edwards, C.A., Arancon, N., \& Holloman, C. (2008). Impact of an exotic earthworm on seed dispersal of an indigenous US weed. Journal of Applied Ecology, 45, 1621-1629.

Rosa, E.V., Giuradelli, T.M., Corrêa, A.X., Rörigand, L.R., Schwingel, P.R., Resgalla, C., \& Radetski, C.M. (2007). Ecotoxicological evaluation of the short term effects of fresh and stabilized textile sludges before application in forest soil restoration. Environmental pollution, 146, 463-469.

Sandhu, H.S., Wratten, S.D., Cullen, R., \& Hale, R. (2005) Evaluating nature's services on Canterbury arable farmland. Technical report. Lincoln: National Centre for Advanced Bio-Protection Technologies, Lincoln University.

Sandhu, H.S., Wratten, S.D., Cullen, R., \& Case, B. (2008) The future of farming: The value of ecosystem services in conventional and organic arable land. An experimental approach. Ecological Economics, 64, 835-848.

Schuldt, M., Rumi, A., Gutiérrez Gregoric, D.E., Caloni, N., Bodnar, J., Revora, N., Tasso, V., Valenti, M., Varela, J., \& De Belaustegui, H. (2005). Culture of Eisenia fetida (Annelida, Lumbricidae) on puffed rice scrap in outdoors and laboratory conditions. Ecologia Austral, 15, 217-227.

Schwenke, G.D., Mulligan, D.R., \& Bell, L.C. (2000). Soil stripping and replacement for the rehabilitation of bauxite-mined land at Weipa. I. Initial changes to soil organic matter and related parameters. Australian Journal of Soil Research, 38, 345-369.

Scullion, J. (2002). Soil degradation and recovery following surface mining. In: J. Rubio, R. Morgan, S. Asins, \& V. Andreu, (Eds), Man and soil at the Third Millennium. Proceedings of the International Congress of the European Society for Soil Conservation, Valencia, Spain, 28 March-1 April, 2000. Volume 2. (pp. 12651276), Logrona, Spain: GEOFORMA Edicions.

Scullion, J., \& Malik, A. (2000). Earthworm activity affecting organic matter, aggregation and microbial activity in soils restored after opencast mining for coal. Soil Biology and Biochemistry, 32, 119-126.

Scullion, J., Mohammed, A.R.A., \& Ramshaw, G.A. (1988). Changes in earthworm populations following cultivation of undisturbed and former opencast coal-mining land. Agriculture, Ecosystems \& Environment, 20, 289-302.

Sengupta, M. (1993). Environmental impacts of mining. Monitoring, Restoration and Control. Boca Raton: Lewis Publishers, CRC Press.

Sheehan, C., Kirwan, L., Connolly, J., \& Bolger, T. (2006). The effects of earthworm functional group diversity on nitrogen dynamics in soils. Soil Biology and Biochemistry, 38, 2629-2636. 
Simberloff, D. (1998). Flagships, umbrellas, and keystones: Is single-species management passé in the landscape era? Biological Conservation, 83, 247-25.

Smyth, C.R., \& Dearden, P. (1998). Performance standards and monitoring requirements of surface coal mine reclamation success in mountainous jurisdictions of western North America: a review. Journal of Environmental Management, 53, 209229.

Snyder, B.A., \& Hendrix, P.F. (2008). Current and potential roles of soil macroinvertebrates (earthworms, millipedes, and isopods) in ecological restoration. Restoration Ecology, 16, 629-636.

Springett, J.A., Gray, R.A.J., Barker, D.J., Lambert, M.G., Mackay, A., \& Thomas, V.J. (1998). Population density and distribution of the New Zealand indigenous earthworm Octochaetus multiporus (Megascolecidae : Oligochaeta) in hill pastures. New Zealand Journal of Ecology, 22, 87-93.

Suthar, S. (2009). Vermistabilization of municipal sewage sludge amended with sugarcane trash using epigeic Eisenia fetida (Oligochaeta). Journal of Hazardous Materials, 163, 199-206.

Suthar, S., \& Singh, S. (2008). Feasibility of vermicomposting in biostabilization of sludge from a distillery industry. Science of The Total Environment, 394, 237-243.

Suthar, S. \& Singh, S. (2009). Bioconcentrations of metals ( $\mathrm{Fe}, \mathrm{Cu}, \mathrm{Zn}, \mathrm{Pb})$ in earthworms (Eisenia fetida), inoculated in municipal sewage sludge: Do earthworms pose a possible risk of terrestrial food chain contamination? Environmental Toxicology, 24, 25-32.

Symondson, W.O.C., Glen, D.M., Erickson, M.L., Liddell, J.E., \& Langdon, C.J. (2000). Do earthworms help to sustain the slug predator Pterostichus melanarius (Coleoptera : Carabidae) within crops? Investigations using monoclonal antibodies. Molecular Ecology, 9, 1279-1292.

Tomati, U., Grappelli, A., \& Galli, E. (1988). The hormone-like effect of earthworm casts on plant-growth. Biology and Fertility of Soils, 5, 288-294.

Topp, W., Simon, M., Kautz, G., Dworschak, U., Nicolini, F., \& Pruckner, S. (2001). Soil fauna of a reclaimed lignite open-cast mine of the Rhineland: improvement of soil quality by surface pattern. Ecological Engineering, 17, 307-322.

Vimmerstedt, J.P. (1983). Earthworm ecology in reclaimed opencast coal mining sites in Ohio. In: J.E. Satchell (Ed.), Earthworm Ecology, from Darwin to vermiculture (pp. 229-240). London: Chapman \& Hall Ltd.

Wall, D.H. (2004). Sustaining Biodiversity and Ecosystem Services in Soils and Sediments. Washington: Island Press. 
598 Wilson, E.O. (1988). Biodiversity. Washington DC: National Academic Press. 